\title{
Standing alone? A review of the characteristics of the entrepreneur through the actor-activity-attitude framework
}

\section{Abstract}

This paper elaborates upon the meaning and nature of the entrepreneur and their special context, involving SMEs in general, and family firms in particular. We review previous literature, based upon a guiding framework around three themes - actor, activity and attitude, developed by Nordquist and Melin (2010). We find that the framework enhances theoretical and empirical understanding of entrepreneurship and family firms. We conclude with reflections on some unexplored themes that have arisen as a result of using this framework and relevant directions for future research on entrepreneurship and family businesses.

Key words: entrepreneur, $3 \mathrm{~A}$ model, actor, activity, attitudes

\section{Introduction}

Nordqvist and Melin (2010) put forward a model for analysing an entrepreneur with the actor-activity-attitude framework (3A model). Actor refers to the distinctiveness of the family unit that is characteristics to this type of business. Activity concerns entrepreneurial actions, and Attitude regards entrepreneurial orientation (Zellweger et al. 2013) and other personal resources as a means for competitive advantage (Chirico-Salvato 2016). These three themes topics and many others will be covered in this section to present an overview of owner-managers and entrepreneurs.

1 PhD, associate professor, Budapest Business School; e-mail: chandler.nick@uni-bge.hu. DOI: http://dx.doi.org/10.31570/Prosp 2019011 1. 
We will consider the personal attributes, skills and behaviour of them as well, in the context of how they compare to the managers and entrepreneurial types of larger organisations. We will look at business start-up motivations and specific entrepreneurial attitudes and styles, and how these may affect strategy implementation. Finally, we consider the culture of the small family business and how specific values and norms characteristic of this form of business may affect its activities as well as its success or failure. This entails a consideration of the concept of familiness, cultural diversity, both on an organisational and national level, and cultural barriers.

\section{Defining entrepreneurs}

If we look for a suitable term for the person that is responsible for small enterprises, then many emerge. Many of the terms indicate a particular interest or activity in the business, such as entrepreneur, owner and manager. However, these activities can be combined, and likewise, the terms are also combined so we have: entrepreneur-owner, entrepreneur-manager, owner-manager and even entrepreneur-owner-manager (Jennings-Beaver 1995).

A true entrepreneur is looking for opportunities and making a difference. In other words, it's about finding something new and applying it to a market, identifying a need and filling it (Schumpeter 1965). Steve Spoonamore is a serial entrepreneur, and a member of Forbes' list of America's most promising companies and explains true entrepreneurs as follows: ${ }^{2}$

'there are people who love to sail the ocean or climb mountains, and more power to them - but it's nowhere near as interesting as taking a technology nobody has heard of, finding a market for it and launching it to your customers. That's satisfying'.

The owner-manager has to climb the mountain of building a business from scratch, and the entrepreneur sees potential and adapts a product or service to fill a need in a particular market. Thus, some owner-managers may be entrepreneurs in its true meaning, but not all.

Entrepreneurs have a crucial role in the national economy as they constitute a driving force for economic development and job creation, not to mention in establishing

2 https://www.forbes.com/sites/brettnelson/2012/06/05/the-real-definition-of-entrepreneur-and-why-itmatters/\#2ce53ae84456. 
local and broader social connections, as well as in terms of personal fulfilment. Maroufkhani et al. (2018) highlight the European Commission's definition of entrepreneurship, which includes a range of personal aspects of the entrepreneur, as a process of enhancing economic activity by taking risk, being creative, innovative and having a suitable management system in an organization (László-Sági 2005). It is this definition which provides the research question for our study of what exactly constitute the characteristics of an entrepreneur.

Within the scope of our definitions of the owner-manager and entrepreneur, we searched for a suitable framework for grouping the many aspects and the following section will cover this in more detail.

\section{The actor-activity-attitude framework}

Nordquist and Melin (2010) reviewed a substantial amount of literature regarding entrepreneurship and the family business, which led them to construct a general guiding framework for this topic as the entrepreneur as an actor, activity of the entrepreneur, and the attitude of the entrepreneur. Through examples of articles in the literature, they argue that research using this framework has great potential to contribute to theoretical and empirical understanding of entrepreneurship and family firms. With this in mind, we will present our review under the headings of each of these three elements.

\section{The actor: the entrepreneur}

If we view the entrepreneur through the $3 \mathrm{~A}$ model, then we need to consider the distinctiveness of the family business or other SME that is characteristic of entrepreneurial start-ups.

A start-up is defined as a newly found business or in the first stage of its operations. However, when Forbes asked business experts, entrepreneurs and owner managers how they defined start-ups, they painted a very different picture. Here is a summary of their findings:

It seems from the table that the central theme is being dynamic and having an impact. This goes beyond our basic definition of simply being a newly found business. A restaurant or franchise may not be considered a start-up in this context, if growth, dynamism and heavy impact are elements of the firm. The Kauffmann foundation has been looking at the rate of start-ups since 1996 and the rate has often seen drops relating to recessions, with the most recent being in 2013 (see Fig. 1): 
Table 1: A range of definitions of a start-up

\begin{tabular}{|l|l|l|}
\hline \multicolumn{1}{|c|}{ DEFINITION } & PERSON & \multicolumn{1}{c|}{ POSITION } \\
\hline $\begin{array}{l}\text { Start-up is a state of mind... when people join } \\
\text { your company and are still making the expli- } \\
\text { cit decision to forgo stability in exchange for } \\
\text { the promise of tremendous growth and the } \\
\text { excitement of making immediate impact. }\end{array}$ & Adora Cheung & $\begin{array}{l}\text { Cofounder and CEO of } \\
\text { Homejoy, one of the Hottest } \\
\text { U.S. Start-ups of 2013 }\end{array}$ \\
\hline $\begin{array}{l}\text { A start-up is a company designed to scale } \\
\text { very quickly. It is this focus on growth } \\
\text { unconstrained by geography which } \\
\text { differentiates start-ups from small businesses. }\end{array}$ & Paul Graham & $\begin{array}{l}\text { Y Combinator accelerator } \\
\text { head }\end{array}$ \\
\hline $\begin{array}{l}\text { It stops being a start-up when people don't feel } \\
\text { as though what they are doing has impact - } \\
\text { an atmosphere that people individually and } \\
\text { collectively can't will the company to success. }\end{array}$ & Russell D'Souza & $\begin{array}{l}\text { Co-founder of ticket search } \\
\text { engine SeatGeek }\end{array}$ \\
\hline $\begin{array}{l}\text { (A start-up involves a) dynamic culture at a } \\
\text { company. (It) gets much harder with every new } \\
\text { employee and with every year that passes. }\end{array}$ & Matt Salzberg & $\begin{array}{l}\text { CEO and cofounder of } \\
\text { dinner set delivery service } \\
\text { Blue Apron }\end{array}$ \\
\hline
\end{tabular}

Source: own from Forbes ${ }^{3}$

Figure 1: The rate of start-up activity from 1996 to 2016

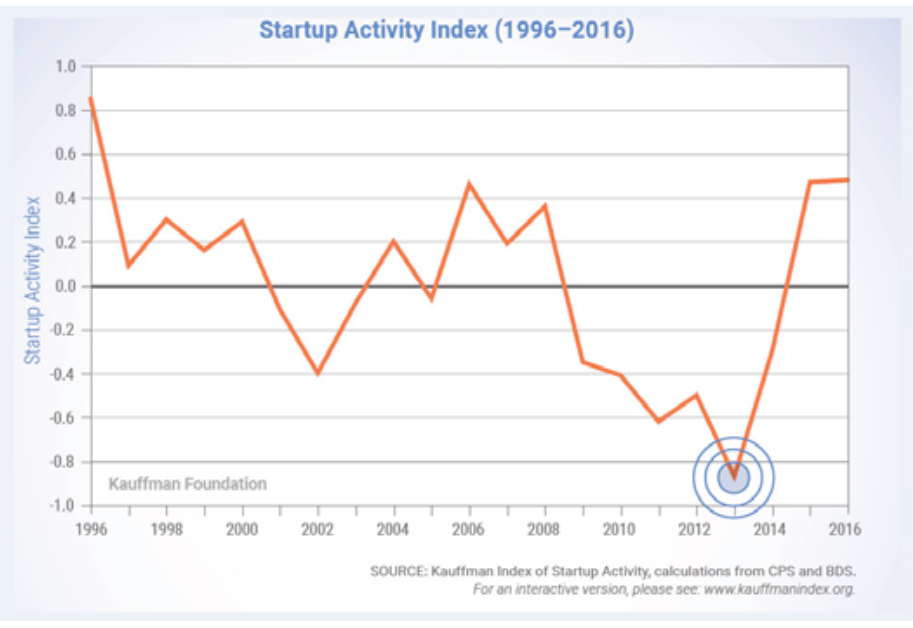

Source: Kauffman et al. (2017)

3 https://www.forbes.com/sites/natalierobehmed/2013/12/16/what-is-a-start-up/\#77c676c40440. 
The figure shows that there has been an increase since the recessions that has brought the rate of start-ups almost to its highest levels over the past twenty years.

Within this context of start-up, we can now consider how entrepreneurs function as actors in the setting of SMEs in general, and family firms in particular. Entrepreneurs and owner-managers of small firms differ from managers of multi-nationals and other larger organisations. Bridge et al. (1998) make the following distinctions for smaller businesses:

- Absence of Functional Managers: as mentioned earlier, the management of a small business remains with one person, necessitating certain skills and attitudes.

- On-the-Job Learning: small business owners are often new to running a business, despite some expertise or experience in a given industry. The missing knowledge of running a business is generally acquired on the job.

- Investment and Resources: the money invested in the business is often personal money rather than received from Venture Capitalists or other impersonal investors. This can lead to an unwillingness to spend money, or a greater focus on short-term returns, when compared to counterparts in larger organisations.

- Discontinuities and limitations: when a large company is overloaded, they may apply for a bigger budget, temporary staff or extra help from another department. In a small business, there may only be one or two people and the labour cost of two extra staff would double i.e. be too high for the small business.

- Identification with the business: A manager in a large multi-national will not have the same personal link to the business as a founder who set up the business and watched it grow

- Values: as will be seen later in this section, the values upheld in a small business will be those of the owner-founder or entrepreneur and can be observed throughout the entire business from quality standards through to the treatment of employees.

Van Driel and Poutsma (1989) also compared SMEs and larger companies and found differences in personal entrepreneurship and direct personal work relations, and division of work. Personal entrepreneurship relates to the personal (financial) contribution to the company that the owner-manager or entrepreneur has made. In small businesses, the degree of work division was found to be lower, whilst at the same time there is a higher degree of autonomy (van Driel-Poutsma 1989). 
In Europe, a small and medium-sized company employs from one to 249 employees and has a yearly turnover of to two to fifty million Euros. Therefore, entrepreneurs and owner managers play a key role in small to medium-sized companies. They have to manage a range of business activities from budgeting and marketing through to human resource management tasks. In many cases, a small business outsources functions such as human resource management or may not perceive them as necessary in the early stages of development of the business.

Although we made a distinction between owner managers and entrepreneurs in the previous section, there are some similarities. For example, they are both overworked and, because of this high workload, they don't have enough time to deal with all management tasks. Here are some of the other characteristics:

\section{Short-termism}

Entrepreneurs and owner-managers also focus on short-term actions and thinking. Therefore, they make decisions on a daily basis or week by week. There is often a single line system in small and medium-sized companies. This means that only the owner manager or the entrepreneur has the right to reach a decision. Consequently, management tasks concentrate on them. This leads to owner manager's or entrepreneur's accumulations of tasks and excessive demands. Because of often missed skills and knowledge and also lack of time and lack of personnel, small and medium-sized enterprises commission business consultants (if they have sufficient funds) who have the tasks of defining and realizing opportunities.

\section{Creativity}

An owner manager should be creative because of the need to develop constructively company policies, systems and procedures. In other words, the creativity is required for the business to function effectively. An entrepreneur not only thrives on the creative process, but cannot set up a business before the creative aspect has come into play by perceiving a need and finding the means to satisfy that need.

\section{People skills}

Assertiveness is needed with the various stakeholders such as suppliers, accountants, or staff, but he should be sensitive as well when he has to mediate differences of opin- 
ion between employees or when he has to deal out criticism to employees. But he also needs the competence in motivating the employees - this is especially important as any staff employed will be required to undertake a range of tasks and activities. It is not unheard for a staff member to be involved in marketing, finance and logistics. Discretion and trustworthiness are essential behaviours which an entrepreneur or an owner manager should have because he knows or works with individual-related data.

\section{Knowledge}

An entrepreneur or an owner-manager should have knowledge in aspects of accounting such as budgeting, marketing techniques, networking and many other areas, since the business often rests on their shoulders alone. One particular aspect of knowledge that is worth consider is that of 'newness' i. e. being new to the arena of running a new small business.

Owner-manager of young firms have to contend with particular difficulties that have been classified as part of the 'liability of newness', which may lead to a greater chance of failure. The causes for failure are all based on the need to learn something new and include: new roles that have to be learned; new routines to solve problems; establishing new social relations with strangers; and new connections with those who use their services (Stinchcombe 1965). This need to learn and develop during the course of growing the business leads to a make or break situation: Carroll (1983) found that organizational death rates decline with firm age. Phillips and Kirchoff (1989) found that three out of five new firms fail within their first six years and Nucci (1999) also found this regardless of industry, size grouping, or region. The new situation was found by Freeman et al. (1983) to depend upon the cooperation of the owner-manager with strangers, whereas older organizations have developed stable and established networks. In a nutshell, the owner-manager is faced with a steep learning curve.

If we turn from the similarities to the differences between entrepreneurs and ownermanagers, then we see some characteristics as specific to one of the two only. Looking first at entrepreneurs, they have the following distinguishing characteristics:

- Drive to solve problems (mastery). Littunen (2000) see mastery as increasing after the start-up phase and, conversely, control by powerful others decreases.

- Opportunity recognition skills were found in a study by Sambasivan et al. (2009) to increase venture performance and these skills acted as a mediator between the qualities and skills of the entrepreneur, and venture performance. 
- Alertness (Sambasivan et al. 2009) also has been found to improve venture performance.

- Prior knowledge of the given area in which the entrepreneur plans to fill the need is also a contributor to better venture performance (Sambasivan et al. 2009). In relation to prior knowledge, some studies have found that the majority of entrepreneurs (56\%) are educated to Bachelor degree level (Okoye-Adigwe 2015).

- Social network skills are needed to establish relationships for collaboration and as a means of overcoming the limited resources and knowledge. Networking is so intense on the part of the entrepreneur, when compared to managers of large businesses that Burns (2002) compares it to the spinning of spiders webs and this is also borne out in the informal organizational structure where staff are also encouraged to network and, thereby, the web gets bigger still. However, with these social networking skills and an informal structure, the entrepreneur communicates directly with all staff, which would be impossible in a larger organisation and has been found to have a limit of around 20-30 employees (Lobontiu G.Lobontiu M. 2014). The following figure highlights this different approach using social network skills:

Figure 2: The growth of the entrepreneurial spider web

a)

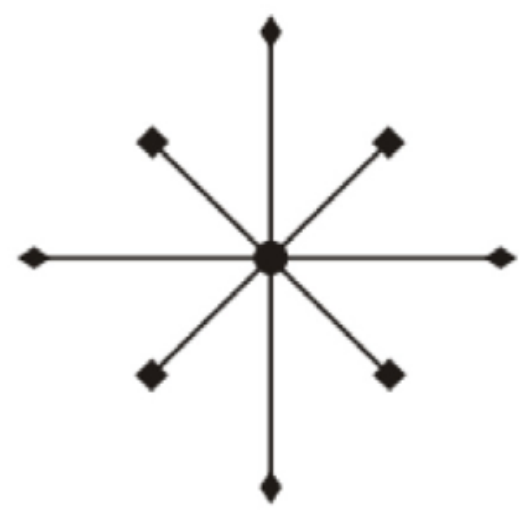

b)

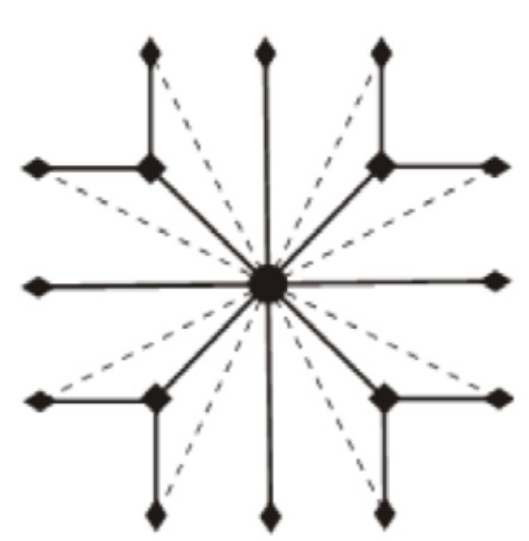

Formal reporting lines

Informal reporting lines 
Social network skills are also seen as a part and package with alertness and prior knowledge that constitute the means by which entrepreneurs recognize opportunities, prior to setting up a business. This is shown in the following figure:

\section{Figure 3: Three key entrepreneurial characteristics and their effects}

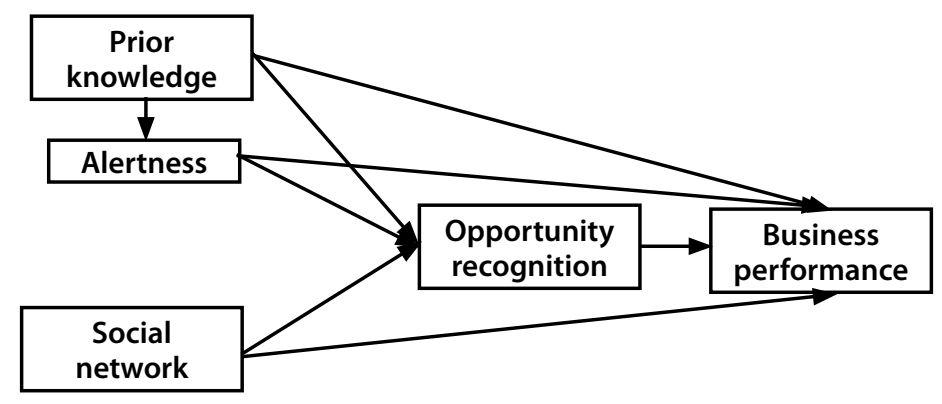

Source: Lim-Xavier (2015)

In this way, we can see the interplay between skills and how the three characteristics lead to the enhancement of opportunity recognition skills, as well as firm performance.

- Vision-centred. According to Mintzberg et al. (2002) in the book Strategy Safari there are ten schools or approaches to strategy. The main focus of the entrepreneurial school is on the leader and his / her vision. The vision is a representation of a strategy existing in the mind of the leader and perhaps can be considered as a vision of the organization's future. The vision is thus seen as an image rather than some advanced plan. As such, the School considers the mental processes of the leader as well as the issues of typology, traits and talents of a leader and entrepreneur.

- Regardless of the differing concepts of a leader and an entrepreneur, Mintzberg's Entrepreneurial School also considers the intuition, wisdom and experience that the leader / entrepreneur employs as a means of strategy formation, although it seems that such strategy formation is an almost semiconscious process.

- The entrepreneur is the key to strategy formation in this School, the vision is promoted by the leader under his close personal control so that specific aspects can be reconsidered if necessary. This implies that power is centralized with the leader and that the leader is likely to be the head of the company, founder or CEO. 
- Risk-taking. The entrepreneur is often characterised as a risk-taker, although entrepreneurs such as Richard Branson, claim that this is calculated risk-taking, rather than a simple gamble.

- Gubitta and Tognazo (2017) highlight that a strong drive or passion to achieve is also required from entrepreneurs. However, passion can be divided into two types: harmonious passion and obsessive passion. The claim that harmonious passion prevails over obsessive passion among entrepreneurs and propose that harmonious passion positively affects entrepreneurs' subjective career success, while obsessive passion has a negative or no impact on it.

There are also personality aspects that could be considered such as narcissistic being one aspect that has been found as characteristic of entrepreneurs (Kets de Vries 1996). A more recent study by Piper (2017) found that narcissism affects a companies' financial performance and that firms' future operational performance can be assessed based on the indicators of CEO narcissism. This would also apply to the case of entrepreneurs - especially form the view that confidence and leadership are misinterpreted and should in fact be seen as narcissism, which could be detrimental to the performance of the firm.

\section{The Activity of the entrepreneur}

Within the context of activity, we will consider two main elements. Firstly, the activity of the entrepreneur setting up their own business and the associated motivations for doing so. Secondly, we will examine the way that an entrepreneur manages a company through their leadership style.

\section{Setting up a business}

The motivation for a start-up centres upon the founder and, as such, vary greatly. For some, it is a social need, because they aspire to be part of a social group (a sense of belonging in Maslow's model). For others, it is the need of self-fulfilment (top of Maslow's hierarchy), because they want to implement their own ideas and having satisfied the lower stages of Maslow's hierarchy of needs in the years of their career, it is time to start up their own company. Thus, a person may decide to start a business, as they are looking for a challenge or some freedom to 'go it alone'. 
This freedom is often referred to as autonomy, but not all entrepreneurs seek autonomy for the same reasons. Van Gelderen and Jansen (2006: 29-30) claim that many entrepreneurs opt for autonomy for the freedom to make their own decisions, others because they simply get tired of following others or following rules (negative freedom). A need for personal independence was also found in a study of entrepreneurs by Estay et al. (2013).

If we consider some of the most successful companies like Apple, Facebook, Microsoft, Google or Disney, they started as a project in a garage or student dormitory. The founders were just persons with a strong intrinsic motivation. As Steve Jobs once said: 'Being the richest man in the cemetery doesn't matter to me. Going to bed at night saying we've done something wonderful... that's what matters to me.'

Shane et al. (2003: 272-273) suggest entrepreneurs are motivated by the need for achievement, locus of control, desire for independence, passion and drive. They suggest that some or all of these motivations influence the entrepreneur from initial recognition of the opportunity through to its realization and the founding of a start-up. The motivation to start a company with a view to growth and impact is also affected by other areas such as knowledge (educational level), experience, skills, abilities as well as the environment of the opportunity, risk and so on (De Clercq-Arenius 2006: 350).

In a study of entrepreneurs in the forestry industry, St-Jean and LeBel (2014) found that motivations were linked to business performance. They found a positive relationship between starting up a forest business for financial success and out of affection for that type of work and business performance. In contrast, they found a negative relationship between starting a business in response to involuntary constraints, motivation and subsequent performance.

Motivation to start up a business is often seen as relating to four categories of entrepreneurs. Firstly, Wanna Be Entrepreneurs have a business idea that they believe would be successful, however they fail to realize the idea due to a lack of confidence, drive, knowledge, or motivation. In other words, one of the bases for the existence of this type of entrepreneur is a lack of motivation - perhaps as they are content enough and feel safe in their current job, or are not motivated enough to take on the risk of leaving a company and going it alone.

Opportunity Entrepreneurs also have a business idea, but the difference is that they act upon it. They are a mixture of people who are self-driven or those who will learn to be. They are motivated by the freedom and fulfillment from being their own boss.

Necessity Entrepreneurs are motivated because they have feel they have no other choice than to start a business. Reasons may vary between inadequate income, job loss, 
or a lack of opportunities to progress in a particular industry (Sági-Korom 2005). The last point is particularly relevant as necessity entrepreneurs have been characterized as generally starting a business in a field related to their expertise or experience. As these entrepreneurs have not chosen this path, their motivation may not be enough for the hard work and energy required to start a business and make it grow. The start-up may be seen as a 'stop-gap' until they can find a job with a decent income or opportunities.

Serial Entrepreneurs love business and get a buzz from the successes achieved. As we saw earlier in the quote from Steve Jobs, it's this rush and sense of fulfilment by making an impact that motivates serial entrepreneurs. So much so, that after having got one business up and running, they are searching for the next idea or opportunity to get off the ground - this explains why entrepreneurs such as Richard Branson have had a role in starting up more than 400 companies.

Within the concept of motivations for founding a business, we can also consider the attitudes that shape a decision to found a business and the reasoning behind that decision. Bergmann (2004a, 2004b, 2005) found that the decision to establish a company was influenced by:

- the self-evaluation of the founder's own foundation capabilities;

- the founder's perception of opportunities for founding a business in a particular region and industry; and

- how the founder handled risk (i.e. the founder's level of risk aversion). This aspect involved other areas such as a fear of failure, self-confidence, background knowledge of the industry, previous experience in founding a business, social networks and so on (see also Sági 2017).

Studies have found that foundation-related attitudes and abilities, such as those listed here, have a significant influence on business foundation activities (Arenius-Minitti 2005).

\section{Leadership}

When we think of leadership, in contrast to management, then leadership can be defined as 'an influence relationship among leaders and followers who intend real changes and outcomes that reflect their shared purposes' (Daft-Lane 2008: 5). The leadership style is the approach taken by an owner-manager or entrepreneur in this influence relationship. Leadership style is seen as achieving sustainable competitive advantage 
through the balancing of four competing criteria: (1) profitability and productivity; (2) continuity and efficiency; (3) commitment and morale; and (4) adaptability and innovation. This balancing is a competence referred to as behavioural complexity and it was found by Hart and Quinn (1993) that higher levels of behavioural complexity lead to better overall firm performance.

However, this does not mean that all leadership styles manage to achieve a suitable balance in their given context. The top management of organizations has the task of guiding the company in a certain direction and devising a strategy to take the company in that direction. If a strategy is not communicated or implanted correctly, then it doesn't matter how good the planned strategy is. Management style adopted by top managers will affect how the strategy is implemented. Certain styles suit specific business situations. When we look at a few examples, bear in mind that in this case, management and leadership are used interchangeably. We will then consider the style(s) most common in entrepreneurs and owner-managers.

Situational Leadership: A situational leader understands the current work-related issues and does what is necessary to solve the problem, such as by allocating the work to the most proficient person for the task. In other words, this kind of manager is focused solely on the situation and can select an appropriate style for that given current situation in strategy implementation.

Transformational Leadership: A strategy is often based upon the future desired direction or vision for the organization. Transformational leadership involves setting attainable goals and sharing the vision of the organization. Transformational leaders see employees as the strength of the organization and want innovative and creative thinking from them - provided it is oriented towards the vision. Employees are involved in the implementation process, and all elements of the strategy is communicated within the scope of the vision.

Transformational Leadership: managers must have the ability to change their employees' perceptions and beliefs, which is no small feat if they have been held for a long time. Thus, transforming employees requires the manager to be charismatic, enthusiastic, optimistic, passionate as well as able to create, communicate and share the vision with the rest of the organization. If the transformational manager is highly effective, then these traits can also be passed onto employees. When this happens, the transformation has taken place, and the strategy can be implemented effectively with the full commitment of all employees, a shared vision, and the necessary traits to implement. For SMEs, this type of leadership is closely linked to the entrepreneur, who is also often dominated by the vision, and displays passion, enthusiasm and creativity. 
Transactional Leadership: Transactional leaders use rewards and punishments to reward good work and punish for failure to meet the leader's expectations. There is a focus on the policies and procedures and some autocracy in decision-making. For owner-managers and entrepreneurs this aspect is particularly relevant as we saw that informal communication to all staff takes place in a spider's web form, but with the entrepreneur or owner manager at the centre of the web making final decisions. However, with such informal approaches, establishing policies and procedures comes later in the growth of the firm generally. This type of leadership is most effective when deviation from the plan may have disastrous results or in times of crisis when employees are looking for 'a hero' to take control and dictate what should be done to get out of the predicament. However, for SMEs there is a caveat: this style is not effective with new or inexperienced staff, since staff are required to blindly follow policies and thus, little learning takes place.

Likewise, for entrepreneurs there is risk to their creativity and innovative thinking, since creative and innovative employees who are highly skilled and experienced may feel they have a lot of ideas to contribute to the entrepreneur's strategy formulation and implementation but will either not be consulted or not have the opportunity to contribute beyond the stipulated procedures. This will likely lead to a common problem found in SMEs of the entrepreneur or owner-manager becoming a 'micromanager' and this in turn will frustrate and demotivate the more talented and experienced employees.

Servant Leadership: The servant leader focuses on the development of staff and so should be empathetic and collaborative. Strategy is implemented in teams as the rationale is 'people first, task second'. If the SMEs has been in operation for some time then this style would work well as it is most effective when the employees are involved with routine tasks. Likewise, conflict can be managed well - this may be important for owner-managers when they reach a stage of growth where non-owner managers are needed and this may result in conflict through a difference in values and perceptions of the most suitable direction for the organisation. However, for SMEs in crisis, this might not be the most suitable style as it lacks direction, and employees tend to need direction in times of crisis, such as that offered by autocratic or transactional leadership.

Laissez-Faire Leadership: This style is often found in the literature to be a barrier to strategy implementation. The leader gives a free rein to employees to do what they want as long as the task is done well and correctly. Thus, in contrast to transactional leadership, there are no policies or procedures and this leads to plenty of scope for creativity. Companies such as ad agencies, social media companies, or those involved in research and development may have leaders with this style. 
As this style requires close monitoring by the owner-manager or entrepreneur, it is not advisable for SMEs with founders struggling with a heavy workload and time commitments. It also is not suitable for very young companies as this style assumes that team members have the skills, knowledge, and motivation to achieve strategy implementation.

Paternal leadership: When we consider SMEs and specifically family businesses, then a paternal leadership style is associated often with this form of business. Paternalistic leadership is often falsely perceived as purely a benevolent, caring style. However, it is 'a style that combines strong discipline and authority with fatherly benevolence' (Farh-Cheng, 2000: 91). Bing (2004) suggested that a leader is reminiscent of the original authority figure for most people: the parent.

Paternalistic leaders may get involved in both professional and personal lives of staff (Gelfand et. al 2007), which is often characteristic of a founder in an SME, but this involvement is not so much an annoying interference as an individualized concern for the personal well-being of staff (Pellegrini-Scandura 2008). Recent research also has distinguished three types of paternalistic leadership as authoritarian, benevolent and moral (Rivers 2015), and Aycan (2006) details the characteristics of these three paternalistic leadership styles as follows: Benevolent paternalistic leadership; Authoritarian paternalistic leadership; and Moral paternalistic leadership. It should be noted that some scholars question the benevolent intent (Padavic-Earnest 1994: 389). Uhl-Bien and Maslyn (2005) see this benevolence as transactional i.e. the leaders expect something in return, resulting (potentially) in indebtedness and oppression on the part of the staff. If these findings bear out, then this style seems closer to transactional leadership.

As a final note on this leadership style, the consequences of this leadership style, despite its prevalence, can be pretty dire for SMEs. Lubatkin et al. (2007) found that the founder's belief in knowing best and acting with best intentions resulting in calculative, coercive and transactional behaviour. The outcome of this behaviour would be that the future successors (children) resent being coerced and manipulated and thereby resist and rebel. However, this reaction might not change the founder's behaviour since it may be seen as the 'necessary cost of parenting. For family firms in particular, this is bad news as 'the more driven by paternalism, the more dysfunctional their firms' intergenerational relationships become' (Lim et al. 2010: 206).

Entrepreneurial Leadership: Needless, to say in the same way paternalistic leadership relates to owner-managers of family firms, entrepreneurs fit into the mould of this style. Leaders are risk takers with a penchant for finding innovative solutions to 
problems. They search for new ideas and make them a reality with creativity, drive, enthusiasm and a strong vision (Daft 2012). There is also a certain degree of drive and independence i.e. not needing to belong to a large company as an employee.

\section{The Attitude of the entrepreneur}

In this section, we will consider entrepreneurial attitudes to and perceptions of the business and running the business - more specifically the characteristics that set entrepreneurs apart from others. We will also look at running the business in general and specific business areas, such as human resources.

Kets de Vries (1996) looks at the attitudes and behaviours of entrepreneurs from the perspective of psychoanalytic theory. In light of the findings of previous studies that entrepreneurial behaviors involve a need for control, a sense of distrust, a desire for applause, and resorting to primitive defensive mechanisms, and the flight into action, Kets de Vries (1996) found that the narcissistic attitudes were actually reactive in nature. Furthermore, he found that running a business was not necessarily a rational process, but that entrepreneurs tended to rationalize the decisions that they had made, retrospectively.

The attitude of entrepreneurs to the future also varies greatly and affect the way the business is managed. The essential question is whether entrepreneurs assume that the future can be controlled or not. Sarasvathy (2001) suggests that there are five principles for entrepreneurial attitudes, if we bear in mind the uncertainty and limited resources of founding a business:

- Bird in hand: this means the entrepreneur chooses to start with one's means.

- Affordable loss: this attitude takes a somewhat more conservative or even negative attitude, as the entrepreneur focusses on the downside of what could be lost and which aspects of the loss are acceptable.

- Crazy-quilt: this attitude involves establishing partnerships (collaboration) and building a network of contacts as a means of overcoming apparent limitations and uncertainty.

- Leveraging contingencies: This attitude necessitates working on an ad hoc basis and making us of unplanned opportunities as the arise.

- Pilot in the plane: This attitude involves the entrepreneur focussing on controlling the environment (internal and external) rather than attempting to predict the future and adapt business operations to those predictions. 
Many of these principles are reminiscent of the approaches taken on by larger companies, as specified in Mintzberg's Strategy Safari, where there are 10 schools of thought prevalent in strategy formulation and implementation. Attitudes to the environment can be seen in the 'Environmental school' along the lines of the 'pilot in the plane principle', leveraging contingencies is seen in the 'contingency school', 'crazy-quilt' is seen in the Cultural and Power schools, and so on.

From an operational perspective, one of the biggest operation changes occurs when entrepreneurs or owner-managers have to start employing non-owner managers for various departments. Watkins (1983) found that owners were often reluctant to delegate responsibilities to newcomers. This stemmed from a perceived need to remain in control and/or a fear that the newcomers would take the business knowledge and use it so set up a business in direct competition with the owner manager. Watkins (1983) also found that any attempts at changing working practices were seen as a criticism of the owner-manager.

\section{Discussion}

Our literature found that the definition of an entrepreneur is somewhat elusive when bearing in mind the many combinations of entrepreneur with owner and manager. Moreover, if we consider the entrepreneur as an entrepreneur within the setting up of an SME, such as a family business, then we are faced with contrasting definition both from empirical studies and practitioners as to what are the defining traits of a business start-up.

Despite this challenge, we have found a number of characteristics in the literature that distinguish the entrepreneur from other actors in the business world, namely mastery, opportunity recognition skills, alertness, prior knowledge of the realm in which the SME resides, and social network skills. Findings in the literature indicate that these characteristics not only distinguish the entrepreneur, but also have a potentially huge impact on the ability of the firm to grow and expand in the longer term.

When we consider the theme of 'activity', we reduced the scope to two main groupings of activities: the start-up phase of the business and leadership during the operation of the business. For the start-up phase, we considered the motivations for starting and business and an overlap emerged as some aspects of motivation were related to attitudes, which formed the third A of our $3 \mathrm{~A}$ model. The entrepreneur's activity in deciding to found a company or not was influenced by attitudes to risk, failure, and self-perception. 
We found that some leadership styles may be seen in SMEs, even though they may stifle the creativity from employees and are not suited to a start-up environment where there is continuous learning, such as the transactional style. We also found that empirical literature focusses on the paternalistic and entrepreneurial styles of leadership for entrepreneurs.

For our final section of attitudes, we also see some over lap with other sections of this framework, namely that attitude can affect activity, which in turn will affect the firm's performance. For example, with the 'crazy-quilt attitude' this will affect the level of entrepreneurial activity in establishing partnerships and building a network of contacts, which in turn will affect the entrepreneur's ability to overcome limitations and uncertainty.

\section{Conclusions}

In this review, we used the framework of the $3 \mathrm{~A}$ model to enhance our understanding of the nature of the entrepreneur. We found that the model serves well as a means of examining key areas, but is limited by the overlapping of two of the three areas, namely activity and attitude as the literature indicates that an entrepreneur's attitude influences the activity or extent to which a particular activity such as taking risks or networking, is undertaken. The link between these two would be an interesting direction for further study insomuch as whether the link indicates a two-way or one-way relationship between activity and attitudes, i. e. can activities also shape attitudes?

Our examination of leadership style and characteristics indicated attitude acts as a mediator of the extent to which skills are employed to undertake certain activities under the premise a certain leadership style. Two research direction arise from this. Firstly, if attitude or leadership style inhibit the skills and activities undertaken. Secondly, whether these areas are fixed for the infancy years of the business, or if the entrepreneur adopts a contingency approach and the activities (motivations and style), and attitudes are directed by the environment in which the actor operates.

Finally, through the use of our 3A model, it's simplicity of three areas help to examine and explain the nature of the entrepreneur. For example, Aldrich and Cliff (2003) and Arregle et al. (2007) highlight that actors of family businesses are set in an ongoing system of social relations and we found that this aspect, amongst others, also came across in our review, as well. However, the framework also serves as a limitation of the areas for reviewing the entrepreneur. Our decision to limit areas such as activities to start-up activity and leadership limits the review further. However, this limitation is 
seen as a necessary one in a field with so much extensive literature and as a means for contributing to theoretical and empirical understanding of entrepreneurship and family firms, as the original developers of the model intended.

\section{References}

Aldrich, H. E. - Cliff, J. E. (2003): The pervasive effects of family on entrepreneurship: toward a family embeddedness perspective. Journal of Business Venturing, 18, 573-596. Arenius, P. - Minniti, M. (2005): Perceptual variables and nascent entrepreneurship. Small Business Economics, (24)3, 233-247. https://doi.org/10.1007/s11187-005-1984-x.

Arregle, J. - Hitt, M. A. - Sirmon, D. G. - Very, P. (2007): The Development of Organizational Social Capital: Attributes of Family Firms. Journal of Management Studies, 44, 73-95. doi:10.1111/j.1467-6486.2007.00665.x.

Aycan, Z. (2006): Human resource management in Turkey. In Budhwar, P. - Mellahi, K. (eds.): Managing Human Resources in the Middle East. London-New York: Routledge, 160-180. https://doi.org/10.1007/s11187-005-1984-x.

Bergmann, H. (2004a): Gründungsaktivitäten im regionalen Kontext. Eine Untersuchung von Gründern, Gründungseinstellungen und Rahmenbedingungen in zehn deutschen Regionen auf der Basis von Mikrodaten. Köln: Wirtschafts- und Sozialgeographisches Institut, Universität zu Köln.

Bergmann, H. (2004b): Determinanten von Gründungsaktivitäten, Zeitschrift für KMU und Entrepreneurship, (52)4, 235-252. https://doi.org/10.3790/zfke.57.2.115.

Bergmann, H. (2005): Entrepreneurial Attitudes - Wodurch werden sie determiniert und welche Rolle spielt die Region? Zeitschrift für Wirtschaftsgeographie, (49)3-4, 185-199.

Bing, S. (2004): Sun Tzu Was a Sissy: Conquer Your Enemies, Promote Your Friends, and wage the Real Art of War. New York: HarperCollins.

Bridge, S. - O’Neil, K. - Cromie, S. (1998): Understanding Enterprise, Entrepreneurship and Small Business. Macmillan, Basingstoke.

https://doi.org/10.1007/978-1-349-26171-0.

Burns, P. (2002): Entrepreneurship and Small Business. Hampshire: Palgrave. https://doi.org/10.1007/978-1-137-43034-2.

Carroll, A. B. (1983): Corporate social responsibility: Will industry respond to cutbacks in social program funding? Vital Speeches of the Day, 49, 604-608. 
Chirico, F. - Salvato, C. (2016): Knowledge internalization and product development in family firms: When relational and affective factors matter. Entrepreneurship Theory and Practice, (40)1, 201-229. Available at SSRN: https://ssrn.com/abstract=2720662 or http://dx.doi.org/10.1111/etap.12114.

Daft, R. (2012): The Leadership Experience. (5th ed.) Mason, OH: Cengage Learning. https://doi.org/10.1108/ejtd-08-2013-0085.

Daft, R. L. - Lane, P. G. (2008): Management. (8th ed.) New York: Thompson SouthWestern.

De Clercq, D. - Arenius P. (2006): The role of knowledge in business start-up activity. International Small Business Journal, (24)4, 339-358.

https://doi.org/10.1177/0266242606065507.

Driel, H. J. van - Poutsma, E. (1989): SME and Control: Autonomy for flexibility. In Poutsma, E. - Walravens, A. (eds.): Technology and Small Enterprises. Technology, Autonomy and Industrial Organisation, 105-123: Delft: Delft University Press.

Estay, C. - Durrieu, F. - Akhter, M. (2013): Entrepreneurship: From motivation to start-up. Journal of International Entrepreneurship, (11)3, 243-267. https://doi.org/10.1007/s10843-013-0109-x.

Farh, J. L. - Cheng, B. S. (2000): A cultural analysis of paternalistic leadership in Chinese organizations. In Li, J. T. - Tsui, A. S. - Weldon, E. (eds.): Management and Organizations in the Chinese Context, 84-127. London: Macmillan. https://doi.org/10.1057/9780230511590.

Freeman, J. - Carroll, G. R. - Hannan, M. T. (1983): The liability of newness: Age dependence in organizational death rates. American Sociological Review, (48)5, 692710. https://doi.org/10.2307/2094928.

Gelderen, M. W. van - Jansen, P. G. W. (2006): Autonomy as a start-up motive. Journal of Small Business and Enterprise Development, (13)1, 23-32.

https://doi.org/10.1108/14626000610645289.

Gelfand, M. J. - Erez, M., - Aycan, Z. (2007): Cross-cultural organizational behavior. Annual Review of Psychology, 58, 479-514.

https://doi.org/10.1146/annurev.psych.58.110405.085559.

Gubitta, P. - Tognazo, A. (2017): Entrepreneurs' Career: Satisfaction, Passion and Depression. EURAM conference 2017 proceedings.

Hart, S. L. - Quinn, R. E. (1993): Roles executives play: CEOs, behavioral complexity, and firm performance. Human Relations, (46)5, 543-574.

https://doi.org/10.1177/001872679304600501. 
Jennings, P. L. - Beaver, G. (1995): The managerial dimension of small business failure. Journal of Strategic Change, (4)4, 185-200. https://doi.org/10.1002/jsc.4240040402. Kauffman, M. - Fairlie, R. - Morelix, A. - Tareque, I. (2017): Kauffman Index of Startup Activity: National Trends. Available at SSRN: https://ssrn.com/abstract=2974462.

Kets de Vries, M. (1996): The anatomy of the entrepreneur: Clinical observations. Human Relations, (49)7, 853-883. https://doi.org/10.1177/001872679604900701.

László, Cs. - Sági, J. (2005): Venture Capital - A Management Approach. 5th International Conference of PhD Students. University of Miskolc Innovation and Technology Transfer Centre.

Lim, W. L. - Xavier, S. R. (2015): Opportunity Recognition Framework: Exploring the Technology Entrepreneurs. American Journal of Economics, (5)2, 105-111.

Lim, E. - Lubatkin, M. H. - Wiseman, R. M. (2010): A family firm variant of the behavioral agency theory. Strategic Entrepreneurship Journal, (4)3, 197-211.

https://doi.org/10.1002/sej.91.

Littunen, H. (2000): Entrepreneurship and the characteristics of the entrepreneurial personality. International Journal of Entrepreneurial Behavior \& Research, (6)6, 295310. https://doi.org/10.1108/13552550010362741.

Lobonţiu, G. - Lobonţiu, M. (2014): The owner-manager and the functional management of a small firm. Procedia - Social and Behavioral Sciences, 124, 552-561. https://doi.org/10.1016/j.sbspro.2014.02.519.

Lubatkin, M. H. - Durand, R. - Ling, Y. (2007): The missing lens in family firm governance theory: A self-other typology of parental altruism. Journal of Business Research, (60)10, 1022-1029. https://doi.org/10.1016/j.jbusres.2006.12.019.

Maroufkhani, P. - Wagner, F. - Khairuzzaman, W. - Ismail, W. (2018): Entrepreneurial ecosystems: A systematic review. Journal of Enterprising Communities: People and Places in the Global Economy, (12)4, 545-564.

https://doi.org/10.1108/JEC-03-2017-0025.

Mintzberg, H. - Ahlstrand, B. W. - Lampel, J. (2002): Strategy Safari: A Guided Tour Through the Wilds of Strategic Management. New York: Free Press.

https://doi.org/10.1108/ws.1999.07948bae.002.

Nordqvist, M. - Melin, L. (2010): Entrepreneurial families and family firms. Entrepreneurship \& Regional Development, (22)3-4, 211-239.

https://doi.org/10.1080/08985621003726119.

Nucci, A. (1999): The demography of business closings. Small Business Economics, (12) 1, 25-39. 
Okoye, N. - Adigwe, P. (2015): Who wants to be an entrepreneur - An insight into the profile of individuals interested in entrepreneurship in Nigeria. European Journal of Business and Management, (7)21, 93-103.

Padavic, I. - Earnest, W. R. (1994): Paternalism as a component of managerial strategy. Social Science Journal, (31)4, 389-405. https://doi.org/10.1016/0362-3319(94)90031-0.

Pellegrini, E. K. - Scandura, T. A. (2008): Paternalistic leadership: A review and agenda for future research. Journal of Management, 34, 566-593.

https://doi.org/10.1177/0149206308316063.

Phillips, B. - Kirchhoff, B. (1989): Formation, growth - survival; small firm dynamics in the US economy. Small Business Economics, (1)1, 65-74.

https://doi.org/10.1007/bf00389917.

Piper, M. (2017): CEO Narcissism and Financial Performance in European Firms. EURAM conference 2017 proceedings. Available at: http://2017.euramfullpaper. org/program/papers.asp (accessed 3rd January 2019).

Rivers, W. (2015): Family Business Leadership Styles. The Family Business Institute, Inc. Available at: http://www.familybusinessunited.com/family-business/ (accessed 3rd January 2019).

Sambasivan, M. - Mohani, A. - Yuzliani, Y. (2009): Impact of personal qualities and management skills of entrepreneurs on venture performance in Malaysia: Opportunity recognition skills as a mediating factor. Technovation, (29)11, 798-805. https:// doi.org/10.1016/j.technovation.2009.04.002.

Sarasvathy, S. D. (2001): Causation and effectuation: Toward a theoretical shift from economic inevitability to entrepreneurial contingency. Academy of Management Review, (26)2, 243-263. https://doi.org/10.2307/259121.

Sági, J. (2017): Credit guarantees in sme lending, role, interpretation and valuation in financial and accounting terms. Economics Management Innovation, (9)3, 62-70.

Sági, J. - Korom, E. (2005): Measures on competitiveness in agriculture. Journal of Central European Agriculture, (6)3, 375-380.

Shane, S. - Locke, E. A. - Collins, C. J. (2003): Entrepreneurial motivation. Human Resource Management Review, 13, 257-279. https://doi.org/10.1016/s10534822(03)00017-2.

Stinchcombe, A. L. (1965): Social structure and organizations. In March, J. G. (ed.): Handbook of Organizations. Chicago: Rand McNally, 142-193.

https://doi.org/10.4324/9780203629130. 
St-Jean, É. - LeBel, L. (2014): The influence of start-up motivations on forest entrepreneurs' performance. Journal of Small Business and Entrepreneurship, (27)4, 392-405. https://doi.org/10.1080/08276331.2015.1088299.

Uhl-Bien, M. - Maslyn, M. (2005): Paternalism as a form of leadership: Differentiating paternalism from leader member exchange. Paper presented at the Annual Meeting of the Academy of Management, Honolulu, Hawaii.

Watkins, D. S. (1983): Development, training and education for the small firm: A European perspective. European Small Business Journal, (1)3, 29-44. https://doi.org/10.1177/026465608200100302.

Zellweger, T. - Nason, R. - Nordqvist, M. - Brush, C. (2013): Why do family firms strive for nonfinancial goals? An organizational identity perspective. Entrepreneurship: Theory and Practice, (37)2, 229-248.

https://doi.org/10.1111/j.1540-6520.2011.00466.x.

This paper was written as part of the project 2016-1-HU01-KA203-022930) ERASMUS+ Strategic Partnership for Higher Education with support of the European Commission. This publication reflects only the views held by the author, and the Commission cannot be held responsible for any use which may be made of the information contained therein. 